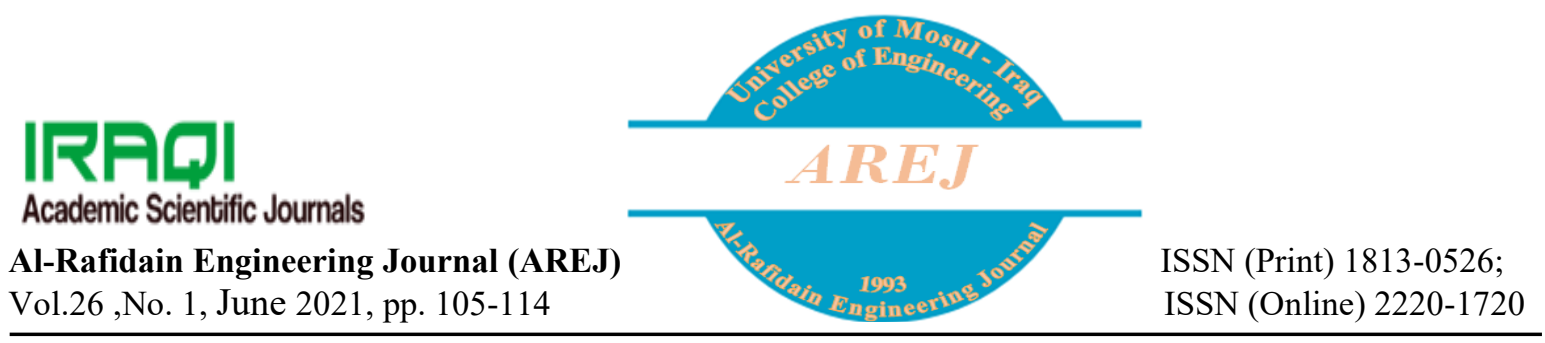

\title{
Improving the Cultivated Area for Ramadi Irrigation Project Using Water Evaluation and Planning Model (WEAP)
}

\author{
Abu Baker A.Najm* $\quad$ Isam M. Abdulhameed ${ }^{* *}$ Sadeq O. Sulaiman*** \\ abubaker_ded@uoanbar.edu.iq isambayati@uoanbar.edu.iq sadeq.sulaiman@uoanbar.edu.iq \\ *,*** Dams and Water Resources Department, College of Engineering, University of Anbar \\ ** Manager of Upper Euphrates Developing Center, University of Anbar
}

Received: 2/9/2020

Accepted: 10/10/2020

\begin{abstract}
In this study, a water evaluation and planning WEAP model was utilized to improve the Ramadi irrigation project with 28342 hectares and 326 million $\mathrm{m}^{3}$ annual budget for the period (2018-2019). The results showed that the total water used was 111.5 million $\mathrm{m}^{3} /$ year representing $34.2 \%$ of Ramadi irrigation budget. The annual production was 39.3 million Kg/year for Ramadi irrigation, and the total economic returns was 16.04 million \$/year. The study proposes two scenarios to improve the cultivated area. The first scenario increases water volume of the current year from 111.5 million $\mathrm{m}^{3}$ year to 272.12 million $\mathrm{m}^{3} /$ year, which caused an increase in annual productivity from $39.3 \mathrm{million} \mathrm{Kg} /$ year to 144.57 million Kg/year, and economic return rose from 16.04 million \$/year to 65.25 million \$/year. The second scenario recorded an increase in the annual production for the current year from 39.3 million Kg/year to 192.27 million Kg/year and economic return from 16.04 million \$year to 86.79 million \$/year when using additional pumps for project 2, 3 and project 5. Also, the convey loss increased from 16.72 million $\mathrm{m}^{3}$ year for the current year to 48.47 million $\mathrm{m}^{3}$ /year when applying the second scenario, which equals $15 \%$ from the water budget of Ramadi irrigation.
\end{abstract}

Keywords:

Improve cultivated area; Improve economic returns; Ramadi irrigation project; WEAP-model

Copyright C $^{2021}$ College of Engineering, University of Mosul, Mosul, Iraq.

https://rengj.mosuljournals.com

Email: alrafidain_engjournal@umosul.edu.iq

\section{INTRODUCTION}

Water is an essential part of the ecosystem; it is a natural resource that cannot be recycled. It has a social and economic significance depending on the quality and quantity of the available water [1]. The water demand is divided into agricultural, domestic, and industrial demand. Agriculture has the largest water share in the various regions of the worldabout $70 \%$ to $90 \%$ in arid and semi-arid regions [2]. The population increase requires providing more water with food to meet local demands.

Due to the limited water resources, it was necessary to achieve a water-management that ensures meeting the water demands of the population [3,21], by raising the efficiency of crop production and saving more water (García et al., 2020).

The Euphrates River is considered the main water resource that provides the water demands for agriculture within the study area.
The water imports of the Euphrates River are shared between Anbar Governorate and the others Iraqi governorates.

The reduction in water imports of Euphrates River leads to reducing the cultivated area within the study area. At the same time, a population growth of about $2 \%$ according to the Anbar Statistics Directorate, requires more water supply with more available food.

The Ramadi irrigation project is 28342 hectares with an annual budget of 326 million $\mathrm{m}^{3} /$ year, with few cultivated areas. It represents $35 \%$ of winter crops, $3.46 \%$ of summer crops and $0.39 \%$ permanent crops, which makes it to necessary to increase the cultivated area to achieve more economic returns with food for population instead of importing crops from outside the governorate or the country.

Some programs like CROPWAT and SIM DUAL appeared during past periods are used to evaluate water consumption of crops. These 
programs deal with field only, which makes it necessary to find a system that deals with all water resource elements [5]. The water evaluation and planning WEAP model comes as a development of these programs, with different tools and methods. It uses assumptions and means to improve the water management of the region. The WEAP model was one of best programs that have set of options and features necessary for water management [6].

\section{MATERIALS AND METHODS}

\subsection{Study area}

The study area located between $33^{\circ} 26^{\prime}$ $84^{\prime \prime} \mathrm{N}$ to $33^{\circ} 22^{\prime} 15.46^{\prime \prime} \mathrm{N}$ Latitude and $43^{\circ}$ $35^{\prime} 36.63$ "E to $42^{\circ} 57^{\prime} 59.50^{\prime \prime}$ E longitude with elevation $53 \mathrm{~m}$ above the sea level as shown in Figure 1. It extends from Abu Tayban west of Ramadi on the right Euphrates River and to end at Al-Malahma to the left of the Euphrates River, east of Ramadi.

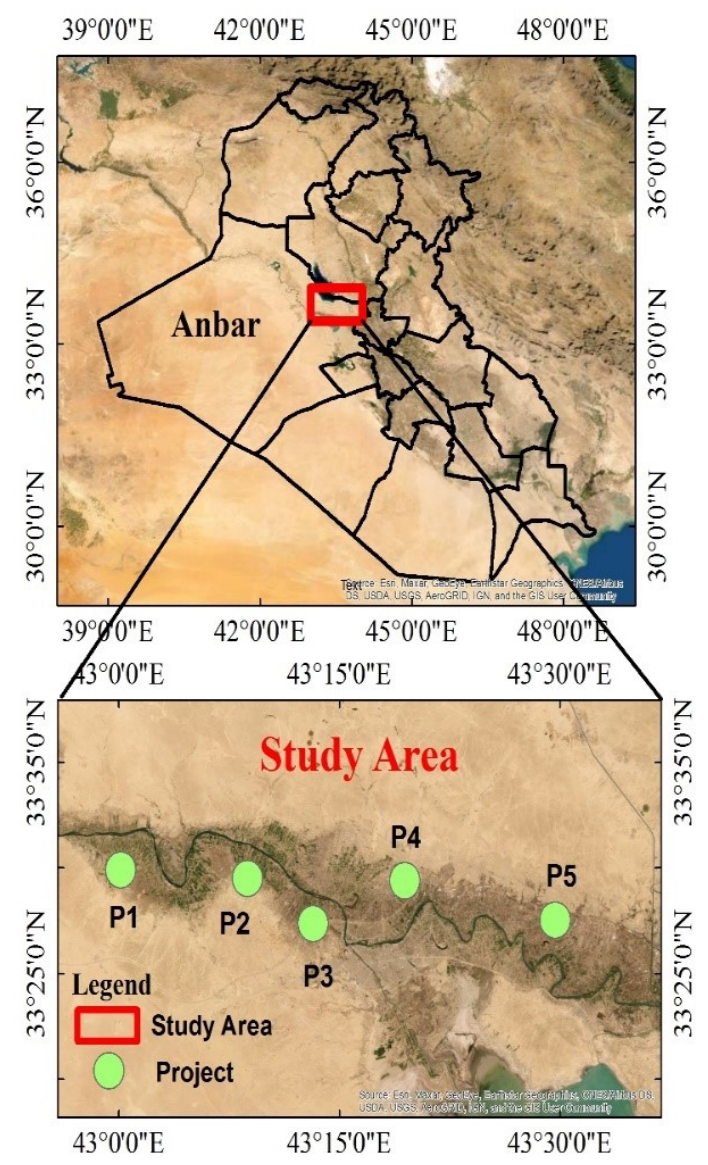

Figure 1. Map of the study area

Ramadi city is the capital of Anbar Governorate and has an important and strategic location, about $108 \mathrm{Km}$ west of Baghdad. It bordered by Salah Al-Din Governorate from the north and northeast, Karbala Governorate from the south and southwest and Hit District from the west [7]. The study area has several water bodies as Tharthar Lake to the north and Habbaniyah Lake to the east of Ramadi city which are used during water shortages periods while Razazah Lake is used for flood protection. Al-Warar stream to the west of Ramadi is used to transport water from the Euphrates River by Al-Warar regulator to Habbaniyah Lake by Al- Warar stream.

\subsection{Irrigation sector}

The Ramadi irrigation has five irrigation projects as in Figure 1. Each project serves several agricultural districts.

Euphrates River is the main source to supply water requirements of crops for each project using pumps establish on the banks of the River. The cultivated area for each irrigation project represented by winter crops as wheat, barley, and Bersame with summer crops as sweet pepper, potato spring, cucumber, sesame, sunflower, tomato, and watermelon, also trees as palm, grape, olives, and citrus in addition to others crops as in Table 1.

The surface irrigation is considered the main method used in each irrigation project with high water losses about $45 \%$ that are not reusable for agricultural. The conveying channels in each irrigation project are lined with losses of about $15 \%$ [8]. The cultivated area in Table 1 was taken from Irrigation Directorate of Anbar, 2019.

Table 1. Cultivated area for each project

\begin{tabular}{|c|c|c|c|c|}
\hline \multirow{2}{*}{ Project } & \multirow[b]{2}{*}{$\begin{array}{c}\text { Area } \\
\text { (ha) }\end{array}$} & \multicolumn{3}{|c|}{ Cultivated area } \\
\hline & & $\begin{array}{l}\text { Winter } \\
\text { Crops \% }\end{array}$ & $\begin{array}{l}\text { summer } \\
\text { Crops \% }\end{array}$ & $\begin{array}{c}\text { Perennial } \\
\text { crops \% }\end{array}$ \\
\hline Projec1 & 3667 & 27.6 & 1.7 & 0.34 \\
\hline Projec2 & 2675 & 66.2 & 6.5 & 0.47 \\
\hline Projec3 & 2500 & 58 & 4.5 & 0.75 \\
\hline Projec4 & 8250 & 44.2 & 3.18 & 0.34 \\
\hline Project5 & 11250 & 18.1 & 3.29 & 0.34 \\
\hline Sum & 28342 & 35 & 3.46 & 0.39 \\
\hline
\end{tabular}

\subsection{Climates conditions}

The climate of the study area is arid and semi-arid; with a limited amount of rainfall- not enough to meet the water requirement of crops [9]. The study area is characterized by the length of the summer season that extends from March to the beginning of October with high temperatures as in Figure 2. The wind differs according to the regions that come from it. The wind passes through the water bodies is characterized by moderate temperatures and high humidity, while the wind that comes from desert areas is characterized by high temperatures and low 
humidity [10]. The daily climate data of the study area was collected from the Iraqi Meteorological Organization and Seismology, 2019.

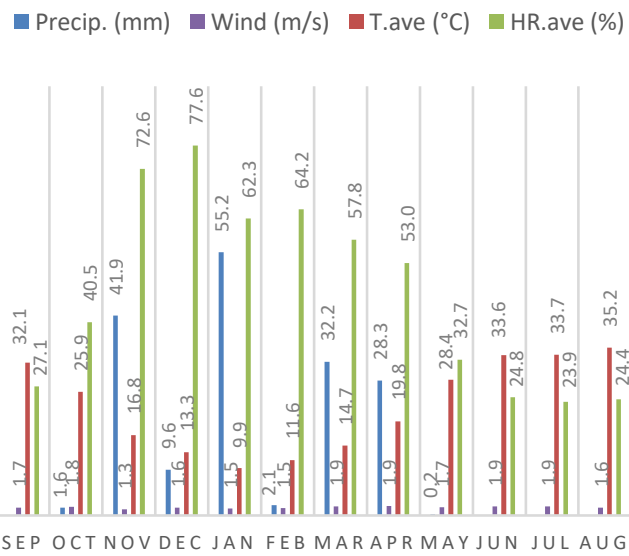

SEP OCT NOVDEC JAN FEB MARAPRMAYJUN JUL AUG

Figure 2.Daily Climate Data from (2018-2019)

\subsection{WEAP modelling process}

The WEAP model calculates Reference Evapotranspiration $\left(\mathrm{ET}_{0}\right)$ using Penman-Monteith equation [11], which assumes the reference surface is green grass with $12 \mathrm{~cm}$ high and $70 \mathrm{~s} / \mathrm{m}$ resistant with an albedo of 0.23 according to the following:

$$
=\frac{0.408 \Delta\left(\mathrm{R}_{\mathrm{n}}-\mathrm{G}\right)+\gamma \frac{900}{\mathrm{ET}_{0}} \mathrm{U}_{2}\left(e_{\mathrm{s}}-\mathrm{e}_{\mathrm{a}}\right)}{\Delta+\gamma\left(1+0.34 \mathrm{U}_{2}\right)}
$$

Where $\mathrm{ET}_{\mathrm{o}}$ represents the reference evapotranspiration $\left(\mathrm{mm}\right.$ day $\left.^{-1}\right), \mathrm{R}_{\mathrm{n}}$ represents net radiation at the surface of the crop ( $\mathrm{MJ} \mathrm{m}^{-2}$ day $\left.^{-1}\right)$, $\mathrm{G}$ represents the density of the soil heat flux (MJ $\mathrm{m}^{-2}$ day $\left.^{-1}\right), \mathrm{T}$ represents average temperature of the daily air at a height of $2 \mathrm{~m}\left({ }^{\circ} \mathrm{C}\right), \mathrm{U} 2$ represents the speed of wind at $2 \mathrm{~m}$ height $\left(\mathrm{m} \mathrm{s}^{-1}\right), \mathrm{e}_{\mathrm{s}}$ represents the vapor pressure of the saturation $(\mathrm{kPa}), e_{a}$ represents the actual vapor pressure $(\mathrm{kPa}), e_{s}-e_{a}$ saturation vapor pressure deficit $(\mathrm{kPa}), \mathrm{D}$ represents the curve of the slope vapor pressure $\left(\mathrm{kPa}{ }^{\circ} \mathrm{C}^{-1}\right)$, and $\mathrm{g}$ represents the psychometric constant $\left(\mathrm{kPa}{ }^{\circ} \mathrm{C}^{-1}\right)$.

The model was provided by Characteristics of crops as planting and harvesting, Basal crop coefficient, depletion factor of the crop, and maximum height as in Figure 3 [11]. The daily climate conditions as precipitation, temperature, wind speed, humidity, elevation above sea level, latitude and longitude of the study area as in Figure 4. The climate conditions effects on the planting and harvesting of crops, which are divided into summer and winter crops with trees. Also, the climate data used to correct values of Basal crop coefficient $\left(\mathrm{K}_{\mathrm{cb}}\right)$ and depletion factor of the crops that taken from FAO-56 [11].

The Dual- $\mathrm{K}_{\mathrm{c}}$ is the approach used by WEAP model, which is considered more complicated than the simple approach, where the crop coefficient $\left(\mathrm{K}_{\mathrm{c}}\right)$ is divided into the "Basal" crop coefficient $\left(\mathrm{K}_{\mathrm{cb}}\right)$ and the $\left(\mathrm{K}_{\mathrm{e}}\right)$ coefficient that represents the evaporation from the soil [12] as in Figure 3. The total crop Evapotranspiration $\left(\mathrm{ET}_{\mathrm{c}}\right)$ is calculated as the result of multiplying the reference Evapotranspiration $\left(\mathrm{ET}_{0}\right)$ by the sum of two coefficients $\left(\mathrm{K}_{\mathrm{cb}}+\mathrm{K}_{\mathrm{e}}\right)$ according to the following equation [13]

$\mathrm{ET}_{\mathrm{c}}=\left(\mathrm{K}_{\mathrm{cb}}+\mathrm{K}_{\mathrm{e}}\right) \mathrm{ET}_{0}$

However, this equation requires adjusted values of $\left(\mathrm{K}_{\mathrm{cb}}\right)$ that is taken from FAO-56 using equation (3), while the daily values $\left(\mathrm{K}_{\mathrm{e}}\right)$ coefficient using daily water balance for topsoil layer as in equation (5)

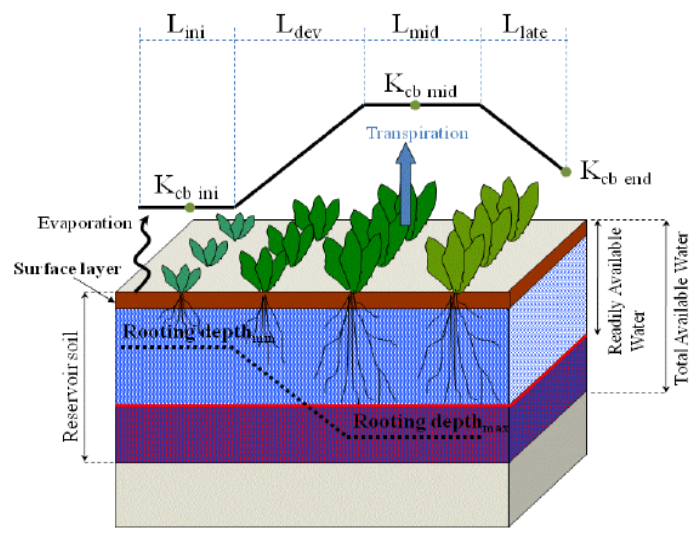

Figure 3. Growth stages of crop [14]

$$
\begin{aligned}
\mathrm{K}_{\mathrm{cb}}= & \mathrm{K}_{\mathrm{cb}}(\mathrm{Tab})+\left[0.04\left(\mathrm{U}_{2}-2\right)\right. \\
& -0.004(\mathrm{RHmin}-45)]\left(\frac{\mathrm{h}}{3}\right)^{3}
\end{aligned}
$$

Where $\mathrm{K}_{\mathrm{cb}}$ (Tab) represents the standard $\mathrm{K}_{\mathrm{cb}}$ value taken from FAO-56 for stage mid and end stage, $U_{2}(\mathrm{~m} / \mathrm{s})$ represents the average of wind speed during the mid or last stage, and $h$ represents the height of the crop during the stage, which is calculated by equation (4).

$\mathrm{h}_{\mathrm{i}}=\frac{\mathrm{K}_{\mathrm{cbi}}}{\mathrm{K}_{\mathrm{cb} \text { mid }}} \mathrm{h}_{\text {max }}$

Where hi represents the crop height on day $\mathrm{i}$ in (m), $K_{\text {cbi }}$ represents the crop basal coefficient on day $\mathrm{i}, \mathrm{K}_{\mathrm{cb} \text { mid }}$ represents the crop basal coefficient 


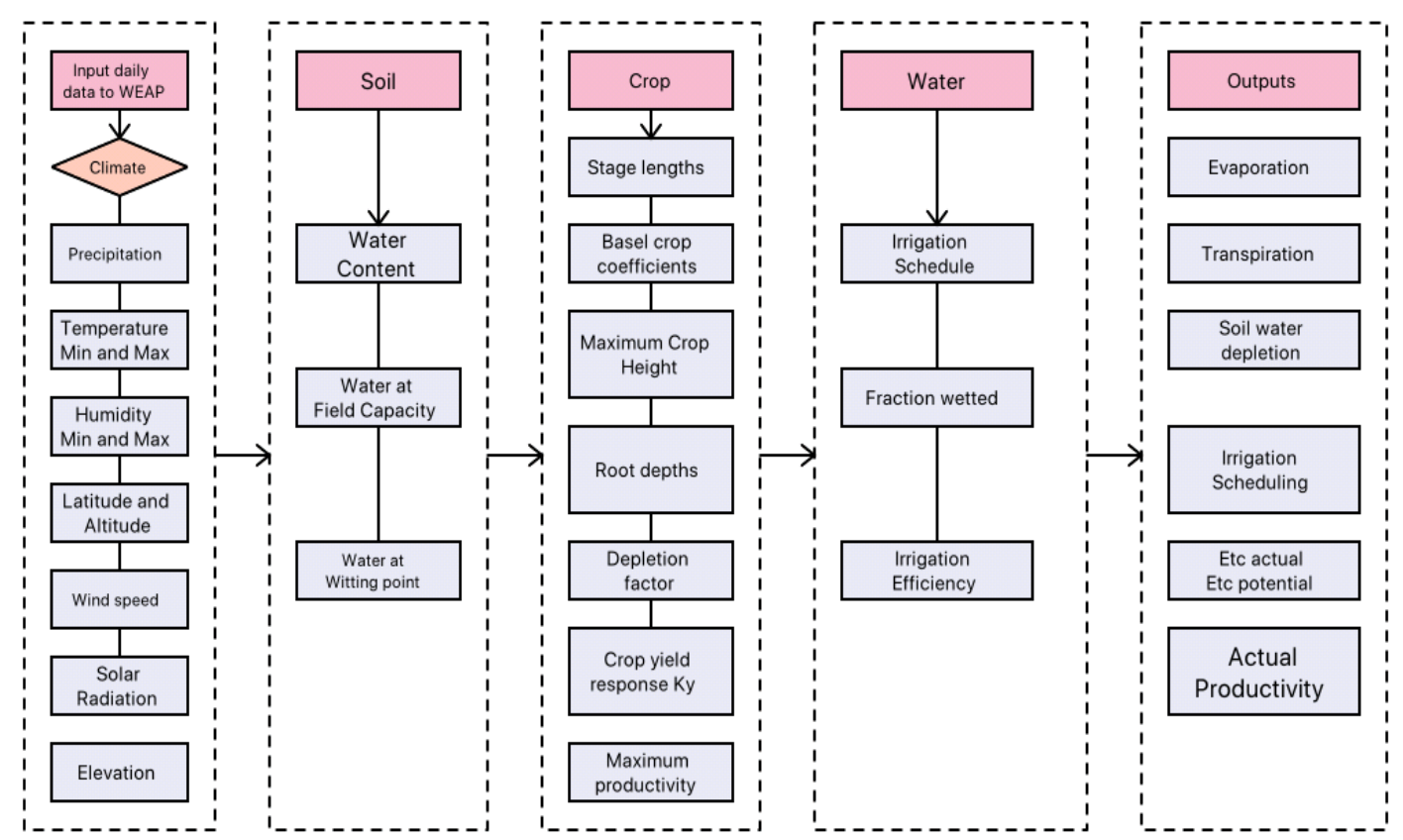

Figure 4.Steps represent the process of WEAP-model

at the mid stage, and $h_{\max }$ represents the height of crop at mid stage in $(\mathrm{m})$.

The water balance was applied for topsoil layer to calculate the daily depletion as following [11]:

$$
\begin{aligned}
D_{e, i}= & D_{e, i-1}-\left(P_{i}-R O_{i}\right) \\
& -\frac{I_{i}}{f_{w}}+\frac{E_{i}}{f_{e w}}+T_{e w, i}+D P_{e, i}
\end{aligned}
$$

Where $\mathrm{D}_{\mathrm{e}, \mathrm{i}-1}$ represents the cumulative depletion depth at the end of previous day $\mathrm{i}-1$ in $(\mathrm{mm}), \mathrm{D}_{\mathrm{e}, \mathrm{i}}$ represents the cumulative depletion depth at the end of day $\mathrm{i}$ in $(\mathrm{mm}), \mathrm{P}_{\mathrm{i}}$ represents Precipitation on day $\mathrm{i}$ in $(\mathrm{mm}), \mathrm{R}_{\mathrm{Oi}}$ represents the amount that exceeds the infiltration of soil and causes runoff on a day $\mathrm{i}$ in $(\mathrm{mm})$, represents the irrigation depth on day $i$ that infiltrates the soil $(\mathrm{mm}), E_{i}$ represents the evaporation on day i (i.e., $E_{i}=K_{e}$ $\left.\mathrm{ET}_{0}\right)(\mathrm{mm}), \mathrm{T}_{\text {ew,i }}$ represents the depth of transpiration from the exposed and wetted fraction of the soil surface layer on day $\mathrm{i}(\mathrm{mm})$, $\mathrm{DP}_{\mathrm{e}, \mathrm{i}}$ represents the deep percolation loss from the topsoil layer on day i if soil water content exceeds field capacity $(\mathrm{mm}), \mathrm{F}_{\mathrm{w}}$ represents the surface of the soil moistened by rain or irrigation $(0.01-1)$, and $\mathrm{F}_{\text {ew }}$ represents the exposed soil and wetted which be subjected to solar radiation $(0.01-1)$.

\subsubsection{Irrigation supplied}

Irrigation is used to supply water at a suitable time when the amount of rainfall is not enough to meet the water requirement. Irrigation is provided according to characteristics of crops, climate conditions during the growth period, soil texture and the irrigation efficiency [15].

In optimal irrigation, WEAP model supplies the water to crops before exceeding the readily available water (RAW), which represents the amount of water used by crop without any stress. RAW equals to the total available water (TAW) multiplied by the depletion factor of crop during the growth stage.

$\mathrm{TAW}=1000\left(\theta_{\mathrm{FC}}-\theta_{\mathrm{WP}}\right) \mathrm{Z}_{\mathrm{r}}$

Where TAW represents the total available water in soil $(\mathrm{mm}), \theta_{\mathrm{FC}}$ represents the water content at field capacity in $\left(\mathrm{m}^{3} \mathrm{~m}^{-3}\right), \theta_{\mathrm{WP}}$ represents the water content at wilting point in $\left(\mathrm{m}^{3} \mathrm{~m}^{-3}\right)$, and $\mathrm{Z}_{\mathrm{r}}$ represents the effective rooting depth in $(\mathrm{m})$.

$\mathrm{RAW}=\mathrm{P}$ TAW

Where RAW represents the readily available water, $\mathrm{P}$ represents the depletion factor of crop, and TAW represent the total available water. The total amount of water with irrigation losses can calculated using the following formula [16]:

$\mathrm{d}_{\mathrm{g}}=\frac{\mathrm{d}_{\mathrm{n}}}{\mathrm{E}_{\mathrm{a}}}$ 
Where $d_{g}$ represents the gross irrigation in $(\mathrm{mm})$, $\mathrm{d}_{\mathrm{n}}$ represents the net water requirement of crop in $(\mathrm{mm})$, and $\mathrm{E}_{\mathrm{a}}$ represents application efficiency.

\subsubsection{Yield module and its parameter}

The productivity of crops under surface irrigation method ( $\mathrm{Kg} / \mathrm{ha})$ was taken from Central Statistical Organization, Iraq 2018 [17], with the unite price for each crop as in Table 2.

The marketing value of crops calculated using WEAP model is by multiplying cultivated area by the yield productivity with the unit price as in the following formula:

$\mathrm{MV}=\mathrm{Y}_{\mathrm{a}} *$ Area $*$ Price

Where MV represent total market value of crop (\$), $Y_{a}$ represents actual yield in $(\mathrm{Kg} / \mathrm{ha})$, Area represents cultivated area in (ha), Price represents unit market price of crop in $(\$ / \mathrm{kg})$.

Water productivity of crops is defined as the ratio between crop yields $(\mathrm{Kg} / \mathrm{ha})$ on the total water applied during the crop season, by irrigation and rainfall [18]. Water productivity of crops can be calculated using the following formula [19]:

$$
W P=\frac{Y_{a}}{T W U}
$$

Where $Y_{a}$ the yield of crop (Kg/ha), and TWU represents the total water applied, which include effective rainfall and losses of irrigation method with net depth irrigation of crop in $\left(\mathrm{m}^{3}\right)$.

Table 2. Yield of crops in central of Iraq, with unite price [17]

\begin{tabular}{|c|c|c|}
\hline Crops & Surface (Kg / ha ) & Price (\$ / Kg) \\
\hline Wheat & 2779 & 0.363 \\
\hline Barley & 1419 & 0.309 \\
\hline Maize & 5444 & 0.467 \\
\hline Cucumber & 10056 & 0.434 \\
\hline Eggplants & 16264 & 0.433 \\
\hline Kidney beans & 5020 & 1.188 \\
\hline Potato Spring & 26983 & 0.476 \\
\hline Sesame & 893 & 1.499 \\
\hline Sunflower & 2226 & 0.725 \\
\hline Sweet Pepper & 8710 & 0.518 \\
\hline Tomato & 26866 & 0.393 \\
\hline Watermelon & 19225 & 0.348 \\
\hline Berseem & 12441 & 0.359 \\
\hline Broad bean & 5802 & 0.516 \\
\hline Cauliflower & 8632 & 0.388 \\
\hline Potato autumn & 26983 & 0.476 \\
\hline
\end{tabular}

\begin{tabular}{|c|c|c|}
\hline Citrus & 4004 & 1.257 \\
\hline Grap & 11800 & 0.713 \\
\hline Olives & 17211 & 1.257 \\
\hline Palm & 9872 & 1.022 \\
\hline
\end{tabular}

3. Results and discussion

The results showes that the total reference evaporation calculated using PenmanMonteith Equation is $1745 \mathrm{~mm}$ / year.

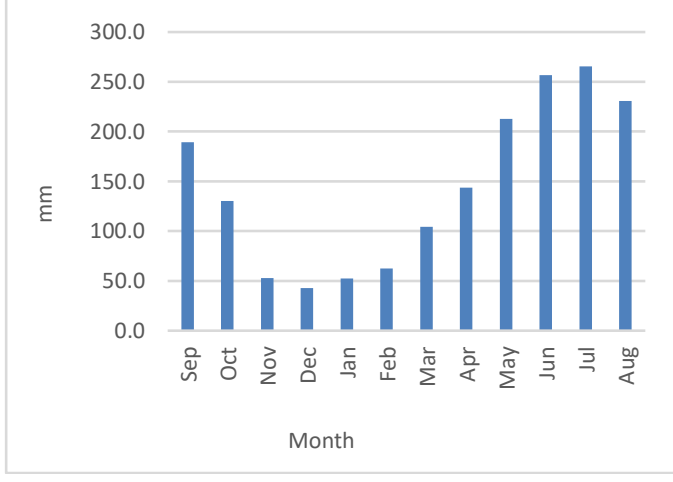

Figure 5. Monthly reference evapotranspiration

There was increasing from March with $104 \mathrm{~mm} / \mathrm{month}$ to reach a peak value at July with $266 \mathrm{~mm} / \mathrm{month}$ while was decreasing during the period from September with $189 \mathrm{~mm} /$ month to reach the minimum value at December with 43 $\mathrm{mm} / \mathrm{month}$ as shown in Figure 5. The increase in irrigation water requirements in summer was due to hot months, for example the wheat crop evapotranspiration $\left(\mathrm{ET}_{\mathrm{c}}\right.$ ) was $43 \mathrm{~mm}$ and $103 \mathrm{~mm}$ for initial and development stage. The mid stage that extends from February until mid-April recorded $282 \mathrm{~mm}$ with $146 \mathrm{~mm}$ for end stage until harvesting at mid-May as in Figure 6.

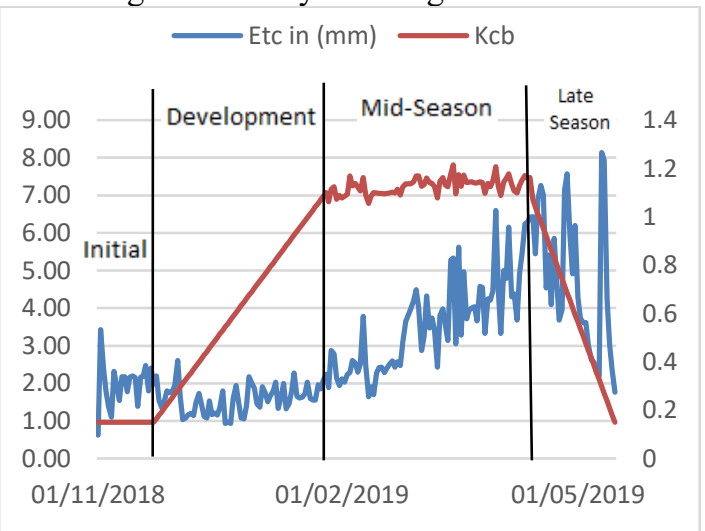

Figure 6. Wheat crop evapotranspiration $\left(\mathrm{ET}_{\mathrm{c}}\right)$ for project1

The water supplied to crop before exceeding the readily available water (RAW), to avoid water stress during the growth season of crops and achieve optimal irrigation as in Figure 
7. Where the differences in (TAW) leads to different (RAW) of Ramadi irrigation projects. The (RAW) depends on the total available water (TAW) with depletion factor of crop (p) during the growth stage.

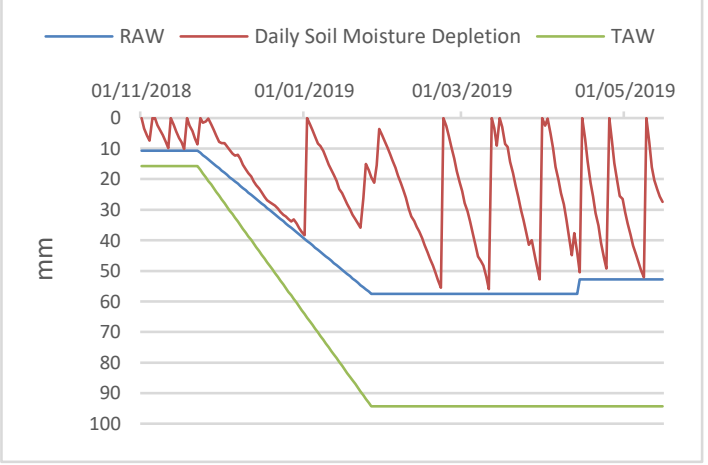

Figure 7. Daily soil depletion with total and readily available water of wheat within project1

The water requirements of each project in Figure 8 were calculated according to the cultivated area with the water requirement of crops for each project as in Table 3.

In November, Strategic crops wheat and barley with winter crops are cultivated, therefor there was water requirement of 8.6 million $\mathrm{m}^{3}$ during this month by multiplying gross irrigation depth by irrigated area. The water demand declined to 1.8 million $\mathrm{m}^{3}$ for December where the month is cold, the evaporation is minimum, and the rainfall contributes in irrigation. The water supply increased during March and April with 20.8 million $\mathrm{m}^{3}$ and 22 million $\mathrm{m}^{3}$ respectively as in Figure 8, where winter and summer crops need more water demand with increasing $\left(\mathrm{ET}_{\mathrm{c}}\right)$ and low depletion factor of crops. In May, the water supply started to decline with the harvesting of strategic crops wheat and barley until reaching the minimum water supply in august 0.5 million $\mathrm{m}^{3}$.

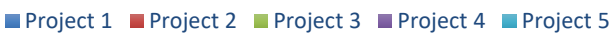

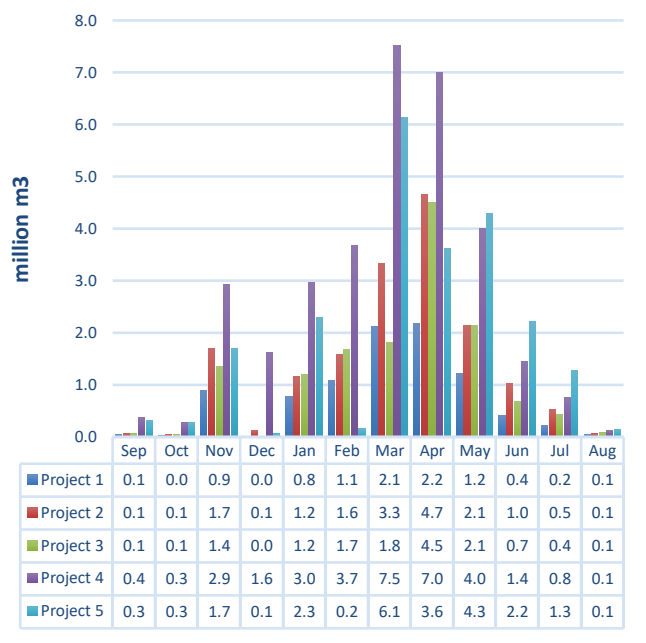

Figure 8. Water requirement for each project (with feild losses)

Table 3. Gross irrigation depth of crops in ( $\mathrm{mm})$

\begin{tabular}{|c|c|c|c|c|c|}
\hline Crops & Pro.1 & Pro.2 & Pro.3 & Pro.4 & Pro.5 \\
\hline Wheat & 780 & 758 & 821 & 787 & 758 \\
\hline Barley & 632 & 658 & 669 & 645 & 671 \\
\hline Maize & 1707 & 1795 & 1789 & 1792 & 1727 \\
\hline Cucumber & 1401 & 1402 & 1411 & 1445 & 1400 \\
\hline Eggplants & 1161 & 1218 & 1216 & 1233 & 1154 \\
\hline Kidney beans & 778 & 819 & 800 & 821 & 779 \\
\hline Potato Spring & 1470 & 1441 & 1449 & 1476 & 1415 \\
\hline Sesame & 1625 & 1582 & 1628 & 1621 & 1619 \\
\hline Sunflower & 1647 & 1718 & 1625 & 1699 & 1646 \\
\hline Sweet Pepper & 1752 & 1768 & 1758 & 1755 & 1750 \\
\hline Tomato & 1519 & 1570 & 1527 & 1591 & 1554 \\
\hline Watermelon & 1544 & 1571 & 1539 & 1602 & 1488 \\
\hline Berseem & 1070 & 1097 & 1074 & 1034 & 1021 \\
\hline Broad bean & 553 & 588 & 554 & 592 & 558 \\
\hline Cauliflower & 1026 & 1016 & 967 & 999 & 983 \\
\hline Potato autumn & 712 & 769 & 713 & 701 & 704 \\
\hline Citrus & 3309 & 3399 & 3420 & 3429 & 3303 \\
\hline Grap & 2389 & 2452 & 2361 & 2526 & 2454 \\
\hline Olives & 2511 & 2762 & 2618 & 2832 & 2539 \\
\hline Palm & 3688 & 3681 & 3644 & 3713 & 3719 \\
\hline
\end{tabular}

The Total water supply represents the total water provided from the river to each project included the field efficiency of $55 \%$ and the conveyance efficiency of lined canal of $85 \%$ [8] as in Table.4.

Table 4. Total water supply from river for each project in (million $\mathrm{m}^{3}$ ) / year

\begin{tabular}{|c|c|c|c|c|c|}
\hline Project & $\begin{array}{c}\text { Pumps } \\
\left(\mathrm{m}^{3} / \mathrm{s}\right)\end{array}$ & $\begin{array}{c}\text { Volume } \\
\text { without } \\
\text { losses }\end{array}$ & $\begin{array}{c}\text { Field } \\
\text { losses }\end{array}$ & $\begin{array}{c}\text { Convey } \\
\text { losses }\end{array}$ & $\begin{array}{c}\text { Water } \\
\text { supply }\end{array}$ \\
\hline Pro.1 & 3.3 & 5.00 & 4.09 & 1.6 & 10.7 \\
\hline
\end{tabular}




\begin{tabular}{|c|c|c|r|c|c|}
\hline Pro.2 & 2.16 & 9.06 & 7.41 & 2.91 & 19.4 \\
\hline Pro.3 & 2.14 & 7.71 & 6.31 & 2.47 & 16.5 \\
\hline Pro.4 & 8.2 & 18.00 & 14.72 & 5.77 & 38.5 \\
\hline Pro.5 & 8.8 & 12.39 & 10.14 & 3.97 & 26.5 \\
\hline Sum & 24.6 & 52.15 & 42.67 & 16.72 & 111.5 \\
\hline
\end{tabular}

The different in water requirement of the projects in Table 4 is related to the cultivated area for each project as in Table 1. The largest water supply was to project 4 and project 5 with 38.5 million $\mathrm{m}^{3} /$ year and 26.5 million $\mathrm{m}^{3} /$ year respectively. It is related to the largest area, which is 8250 ha and 11250 ha for project 4 and project 5 with cultivated area of winter and summer crops of $58 \%$ with $4.5 \%$ for project 4 and $44 \%$ with $3.18 \%$ for project 5 as in Table 1 .

The amount of water used in production in Table 5, representes the sum of the gross irrigation depth of crop with the effective rainfall, and the result is multiplied by cultivated area of crop.

Table 5. Total water used in production in (million $\mathrm{m}^{3}$ /year)

\begin{tabular}{|c|l|l|l|l|l|}
\hline Crops & Pro.1 & Pro.2 & Pro.3 & Pro.4 & Pro.5 \\
\hline Wheat & 8.71 & 15.33 & 12.24 & 27.16 & 16.36 \\
\hline Barley & 0.96 & 2.21 & 1.59 & 5.93 & 0.83 \\
\hline Maize & 0.66 & 1.81 & 1.14 & 1.42 & 3.85 \\
\hline Cucumber & 0.04 & 0.12 & 0.08 & 0.31 & 0.23 \\
\hline Eggplants & 0.03 & 0.10 & 0.07 & 0.26 & 0.20 \\
\hline Kidney beans & 0.02 & 0.07 & 0.04 & 0.17 & 0.13 \\
\hline Potato Spring & 0.04 & 0.12 & 0.08 & 0.32 & 0.26 \\
\hline Sesame & 0.04 & 0.13 & 0.09 & 0.34 & 0.27 \\
\hline Sunflower & 0.05 & 0.14 & 0.09 & 0.36 & 0.29 \\
\hline Sweet Pepper & 0.05 & 0.16 & 0.11 & 0.40 & 0.34 \\
\hline Tomato & 0.04 & 0.13 & 0.09 & 0.33 & 0.27 \\
\hline Watermelon & 0.04 & 0.13 & 0.09 & 0.34 & 0.26 \\
\hline Berseem & 0.04 & 0.06 & 0.04 & 0.48 & 0.40 \\
\hline Broad bean & 0.02 & 0.04 & 0.02 & 0.29 & 0.24 \\
\hline Cauliflower & 0.03 & 0.05 & 0.04 & 0.42 & 0.33 \\
\hline Potato autumn & 0.02 & 0.04 & 0.02 & 0.28 & 0.25 \\
\hline Citrus & 0.11 & 0.11 & 0.16 & 0.25 & 0.32 \\
\hline Grap & 0.08 & 0.08 & 0.12 & 0.18 & 0.24 \\
\hline Olives & 0.08 & 0.09 & 0.12 & 0.20 & 0.27 \\
\hline Palm & 0.12 & 0.12 & 0.18 & 0.27 & 0.37 \\
\hline
\end{tabular}

In Table 5, the total water used in production represents the sum of the gross irrigation of crops with effective rainfall, product by the cultivated area of the crop within the project. The water productivity was different between irrigation projects as in Table 6 due to the different soil texture of each project, which caused differences in water supply and as aresult, diffrences in water productivity.

Table 6. Water productivity of crops $(\mathrm{kg} / \mathrm{m} 3)$

\begin{tabular}{|l|l|l|l|l|l|}
\hline Crops & P.1 & P.2 & P.3 & P.4 & P.5 \\
\hline Wheat & 0.28 & 0.27 & 0.28 & 0.28 & 0.31 \\
\hline Barley & 0.19 & 0.16 & 0.17 & 0.18 & 0.17 \\
\hline Maize & 0.30 & 0.30 & 0.30 & 0.29 & 0.30 \\
\hline Cucumber & 0.75 & 0.67 & 0.63 & 0.68 & 0.74 \\
\hline Eggplants & 1.33 & 1.30 & 1.29 & 1.31 & 1.40 \\
\hline Kidney beans & 0.50 & 0.57 & 0.75 & 0.59 & 0.69 \\
\hline Potato Spring & 1.75 & 1.83 & 1.88 & 1.75 & 1.77 \\
\hline Sesame & 0.05 & 0.08 & 0.06 & 0.06 & 0.07 \\
\hline Sunflower & 0.20 & 0.14 & 0.13 & 0.14 & 0.14 \\
\hline Sweet Pepper & 0.60 & 0.50 & 0.45 & 0.50 & 0.47 \\
\hline Tomato & 1.75 & 1.69 & 1.67 & 1.67 & 1.70 \\
\hline Watermelon & 1.25 & 1.23 & 1.11 & 1.18 & 1.27 \\
\hline Berseem & 1.00 & 1.00 & 1.00 & 0.98 & 1.00 \\
\hline Broad bean & 1.00 & 0.75 & 1.00 & 0.76 & 0.75 \\
\hline Cauliflower & 1.00 & 0.80 & 0.75 & 0.76 & 0.82 \\
\hline Potato autumn & 4.00 & 3.25 & 4.00 & 3.61 & 3.44 \\
\hline Citrus & 0.09 & 0.09 & 0.13 & 0.12 & 0.13 \\
\hline Grap & 0.50 & 0.50 & 0.50 & 0.44 & 0.46 \\
\hline Olives & 0.63 & 0.56 & 0.67 & 0.60 & 0.59 \\
\hline Palm & 0.25 & 0.25 & 0.28 & 0.26 & 0.24 \\
\hline
\end{tabular}

Table 7. Total Production and economic return in (million)

\begin{tabular}{|c|c|c|}
\hline Projects & $\begin{array}{c}\text { Production } \\
\text { (Kg/year) }\end{array}$ & $\begin{array}{c}\text { Total returns } \\
\text { (\$/ year) }\end{array}$ \\
\hline Project 1 & 3.4 & 1.37 \\
\hline Project 2 & 6.4 & 2.56 \\
\hline Project 3 & 5.1 & 2.05 \\
\hline Project 4 & 13.8 & 5.58 \\
\hline Project 5 & 10.5 & 4.47 \\
\hline Sum & 39.3 & 16.04 \\
\hline
\end{tabular}

The total production for the current year was 39.3 million $\mathrm{Kg} /$ year with economic returns of 16.04 million $\$ /$ year as in Table 7 . The total water supply from the river was 111.5 million $\mathrm{m}^{3}$ /year, represented by the gross irrigation with conveyance losses of 16.72 million $\mathrm{m}^{3} /$ year. The conveyance losses were not used in production due to water productivity including water applied in field with the effective rainfall.

The total water supply from the river was $111.5 \mathrm{~m}^{3} /$ year, and equal $34.2 \%$ from water budget from Euphrates, which was 326 million $\mathrm{m}^{3}$ /year. The economic returns from project 4 and 5 were the largest compared to the other projects, and the reason related to the large cultivated area of these projects compare to the other projects as in Table 1. Although the few cultivated area for project 4 and 5, but it was the larges plants with crops. There for the total 
economics returns were 5.58 with 4.47 million $\$ /$ year on respectivitly.

\subsection{Improve cultivated area}

The water budget for the irrigation project was 326 million $\mathrm{m}^{3} /$ year and the amount of water used in irrigation was 111.5 million $\mathrm{m}^{3} /$ year including all losses. The percent of unused water was $65.8 \%$. Therefore it was necessary to improve the cultivated area to achieve more production with more economic returns.

\subsubsection{First scenario}

Improving the cultivated area for Table 1 was without adding new operation pumps for projects with evaluating the annual production and economic returns.

Table 8. The percent of Increasing in cultivated area of projects

\begin{tabular}{|c|c|c|c|c|c|c|}
\hline \multirow{2}{*}{} & \multicolumn{3}{|c|}{ Winter crps } & \multicolumn{2}{c|}{ Summer crops } & \multirow{2}{*}{ Tress } \\
\cline { 2 - 6 } & Wheat & Barley & Other & Maize & Other & \\
\hline Pro.1 & $+4 \%$ & $+15 \%$ & $+25 \%$ & $+2 \%$ & $+20 \%$ & $+4 \%$ \\
\hline Pro.4 & $+10 \%$ & ------ & $+24 \%$ & $+1 \%$ & $+15 \%$ & $+2 \%$ \\
\hline Pro.5 & $+30 \%$ & $+5 \%$ & $+7 \%$ & $+2 \%$ & $+5 \%$ & $+3 \%$ \\
\hline
\end{tabular}

The increase in cultivated area in Table 8 is based on the Priority of saving water. For example, the barley crop needs gross irrigation depth of $632 \mathrm{~mm} /$ year and $672 \mathrm{~mm} /$ year for project 1 and 5 , respectively. Therefore, the increase was $35 \%$ and $5 \%$ for project 1 and 5 respectivitly. As well for wheat crop, it needed gross irrigation of $821 \mathrm{~mm}$ and $758 \mathrm{~mm}$ for project 3 and 5, respectively. Therefore, it increase by $30 \%$ for project 5 .

The cultivated area in Table 8 did not increase for Project 2 and 3 because the pumps were not enough to cultivate more crops. This required increasing the pumps for the project to cover all demand during all months, where the need occurred during hot months with increased crops water requirements. The water discharge of pumps for projects $1,2,3,4$, and 5 were $3.3,2.16$, $2.14,8.2$, and $8.8 \mathrm{~m}^{3} / \mathrm{s}$, respectively.

Table 9.Total cultivated area of Ramadi irrigation project by scenario 1 after Improving

\begin{tabular}{|c|c|c|c|c|}
\hline & \multirow{2}{*}{$\begin{array}{l}\text { Area } \\
\text { (ha) }\end{array}$} & \multicolumn{3}{|c|}{ Cultivated area after applied First scenario } \\
\hline & & $\begin{array}{l}\text { Winter } \\
\text { crops } \%\end{array}$ & $\begin{array}{l}\text { Summer } \\
\text { crops } \%\end{array}$ & $\begin{array}{c}\text { Perennial } \\
\text { crops } \%\end{array}$ \\
\hline Pro.1 & 3667 & 71.6 & 23.7 & 4.34 \\
\hline Pro. 2 & 2675 & 66.2 & 6.5 & 0.47 \\
\hline Pro.3 & 2500 & 58 & 4.5 & 0.75 \\
\hline Pro.4 & 8250 & 78.2 & 19.18 & 2.34 \\
\hline Pro.5 & 11250 & 60.1 & 10.29 & 3 \\
\hline
\end{tabular}

\begin{tabular}{|l|l|l|l|l|}
\hline Sum & 28342 & 67.7 & 13.4 & 2.6 \\
\hline
\end{tabular}

The additional cultivated area as in Table 9 increased the irrigation volume by $144 \%$ from 111.5 million $\mathrm{m}^{3}$ /year to 272.12 million $\mathrm{m}^{3} /$ year. The economic returns increased by $307 \%$ from 16.04 million \$/year to 65.24 million $\$ /$ year as in Table 10. The unused water reached 54 million $\mathrm{m}^{3}$ /year, which equals to $17 \%$ from water budget and to use it, more pumps are required for the projects.

Table 10. Total Production and economic return in (million)

\begin{tabular}{|c|c|c|c|}
\hline Projects & $\begin{array}{c}\text { Total water } \\
\text { supply with } \\
\text { losses }\left(\mathrm{m}^{3}\right)\end{array}$ & $\begin{array}{c}\text { Production } \\
(\mathrm{Kg} / \text { year })\end{array}$ & $\begin{array}{c}\text { Total } \\
\text { returns } \\
\text { \$/ year })\end{array}$ \\
\hline Project 1 & 46.92 & 28.83 & 13.33 \\
\hline Project 2 & 19.37 & 6.42 & 2.56 \\
\hline Project 3 & 16.49 & 5.09 & 2.05 \\
\hline Project 4 & 94.78 & 60.94 & 27.4 \\
\hline Project 5 & 94.55 & 43.29 & 19.9 \\
\hline Sum & 272.12 & 144.57 & 65.25 \\
\hline
\end{tabular}

\subsubsection{Second scenario}

In this scenario new pumps were added to use all water budget of Ramadi irrigation project. The pumps increased from 2.16 to 3.16 $\mathrm{m}^{3} / \mathrm{s}, 2.14$ to 3.14 , and from 8.8 to 10.8 for projects 2,3 , and 5 respectively.

Table 11. The percent of Increasing in cultivated area of projects under second scenario

\begin{tabular}{|c|c|c|c|c|c|c|}
\hline & \multicolumn{3}{|c|}{ Winter crps } & \multicolumn{2}{c|}{ Summer crops } & \multirow{2}{*}{ Tress } \\
\cline { 2 - 6 } & Wheat & Barley & Other & Maize & Other & \\
\hline Pro.1 & $+4 \%$ & $+15 \%$ & $+25 \%$ & $+2 \%$ & $+20 \%$ & $+4 \%$ \\
\hline Pro. 2 & ----- & ----- & $+20 \%$ & ----- & $+5 \%$ & ---- \\
\hline Pro.3 & ----- & ---- & $+10 \%$ & ---- & $+18 \%$ & ---- \\
\hline Pro.4 & $+10 \%$ & ----- & $+24 \%$ & $+1 \%$ & $+15 \%$ & $+2 \%$ \\
\hline Pro.5 & $+30 \%$ & $+10 \%$ & +17 & $+2 \%$ & $+5 \%$ & $+3 \%$ \\
\hline
\end{tabular}

Table 12. Production of projects with economic return in (million)

\begin{tabular}{|c|c|c|c|}
\hline Projects & $\begin{array}{c}\text { Total water } \\
\text { supply with } \\
\text { losses }\left(\mathrm{m}^{3}\right)\end{array}$ & $\begin{array}{c}\text { Production } \\
(\mathrm{Kg})\end{array}$ & $\begin{array}{c}\text { Total } \\
\text { returns } \\
(\$ / \text { year })\end{array}$ \\
\hline Project 1 & 46.92 & 28.83 & 13.33 \\
\hline Project 2 & 26.20 & 14.65 & 6.21 \\
\hline Project 3 & 26.56 & 14.21 & 6.25 \\
\hline Project 4 & 94.78 & 60.94 & 27.40 \\
\hline Project 5 & 128.68 & 73.64 & 33.60 \\
\hline
\end{tabular}




\begin{tabular}{|l|l|l|l|}
\hline Sum & 323.14 & 192.27 & 86.79 \\
\hline
\end{tabular}

Table 13. Total cultivated area of project by second scenario after Improving

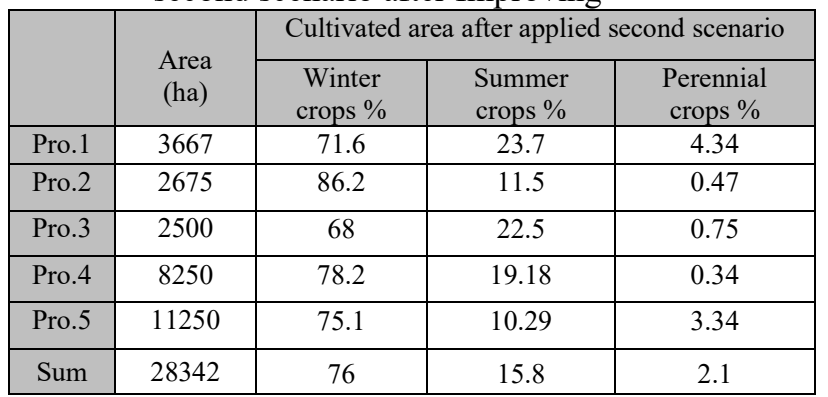

\section{Conclusion}

1- The water used for Ramadi irrigation project represent $34.2 \%$ from Ramadi irrigation budget from Euphrates River.

2- Despite of, the total water requirement increased by $144 \%$ from $111.5 \mathrm{~m}^{3} /$ year to 272.12 $\mathrm{m}^{3} /$ year, the economic returns increased by $307 \%$ from 16.04 million \$/year to 65.24 million \$.

3 - When using additional pumps for project 2 and project 3 by $1 \mathrm{~m}^{3} / \mathrm{s}$ and $2 \mathrm{~m}^{3} / \mathrm{s}$ for project 5 , respectively, the economics return increased by $441 \%$ from 16.04 million $\$ /$ year to 86.79 million $\$ /$ year.

4- The convey loss increased from 16.72 million $\mathrm{m}^{3}$ /year to 48.47 million $\mathrm{m}^{3} /$ year, when applied second scenario.

\section{REFERENCES}

[1] Á. F. Morote, J. Olcina, and M. Hernández, "The use of non-conventional water resources as a means of adaptation to drought and climate change in semi-arid regions: South-eastern Spain," Water (Switzerland), vol. 11, no. 1, 2019, doi: 10.3390/w11010093.

[2] J. M. Martínez-Paz, F. Gomariz-Castillo, and F. Pellicer-Martínez, "Appraisal of the water footprint of irrigated agriculture in a semi-arid area: The Segura River basin," PLoS One, vol. 13, no. 11, pp. 1-20, 2018, doi: 10.1371/journal.pone.0206852.

[3] UNESCO, "Water for a sustainable world," United Nations world water Dev. Rep., p. 122, 2015.

[4] I. F. García et al., "Trends and challenges in irrigation scheduling in the semi-arid area of Spain," Water (Switzerland), vol. 12, no. 3, pp. 1-26, 2020, doi: 10.3390/w12030785.

[5] Z. Gu, Z. Qi, R. Burghate, S. Yuan, X. Jiao, and J. Xu, "Irrigation Scheduling Approaches and Applications: A Review,” J. Irrig. Drain. Eng., vol. 146, no. 6, p. 04020007, 2020, doi: 10.1061/(asce)ir.1943-4774.0001464.

[6] J. Sieber and D. Purkey, "Ser uide," Environment, no. August, p. 343, 2011, [Online]. Available: http://www.weap21.org/WebHelp/index.html.

[7] S. L. M Al Dulaimy, "Water resources in the Ramadi district and their importance in agricultural production" thesis is submitted to the Council of the College of Education for Humanities in Anbar University , 2018.

[8] G.Popescu and A. Jean-Vasile "Agricultural Management Strategies in a Changing Economy“, Hershey: IGI Global, 2015 p. 439. ISBN 978-1466675216. DOI 10.4018/978-14666-7521-6.

[9] N. Adamo, N. Al-Ansari, V. K. Sissakian, S. Knutsson, and J. Laue, "Climate Change: Consequences on Iraq's Environment," J. Earth Sci. Geotech. Eng., vol. 8, no. 3, pp. 1792-9660, 2018.

[10] J. L. Hatfield et al., "Climate impacts on agriculture: Implications for crop production," Agron. J., vol. 103, no. 2, pp. 351-370, 2011, doi: 10.2134/agronj2010.0303.

[11] R.G.Allen, L.S.Pereira, , D.Raes, , M.Smith, Crop evapotranspiration: guide-lines for computing crop water requirements. In: FAO Irrigation and Drainage Paper No. 56. FAO, Rome, Italy, 300 pp. 1998.

[12] R. G. Allen et al., "FAO-56 Dual Crop Coefficient Method for Estimating Evaporation from Soil and Application Extensions," no. February, pp. 2-13, 2005.

[13] R. Awal, H. Habibi, A. Fares, and S. Deb, "Estimating reference crop evapotranspiration under limited climate data in West Texas," J. Hydrol. Reg. Stud., vol. 28, no. March, p. 100677, 2020, doi: 10.1016/j.ejrh.2020.100677.

[14] M. Jabloun and A. Sahli, "WEAP-MABIA Tutorial," no. January, p. 97, 2012.

[15] K. Chartzoulakis and M. Bertaki, "Sustainable Water Management in Agriculture under Climate Change," Agric. Agric. Sci. Procedia, vol. 4, pp. 88-98, 2015, doi: 10.1016/j.aaspro.2015.03.011.

[16] M. Brouwer, C., K. Prins, Heibloem, "Irrigation Water Management: Irrigation Scheduling," Train. Man., no. 4, p. 66, 1989, [Online]. Available:

ftp://ftp.fao.org/agl/aglw/fwm/Manual4.pdf.

[17] Central Statistical Organization Iraq. Agricultural crop productivity reports for 2018. From http://www.cosit.gov.iq/ar/agri-stat/veg-prod

[18] R. Flach, R. Skalský, C. Folberth, J. Balkovič, K. Jantke, and U. A. Schneider, "Water productivity and footprint of major 
Brazilian rainfed crops - A spatially explicit analysis of crop management scenarios," Agric. Water Manag., vol. 233, no. May 2019, p. 105996, 2020, doi: 10.1016/j.agwat.2019.105996.

[19] T. A. Paço, P. Paredes, L. S. Pereira, J. Silvestre, and F. L. Santos, "Crop coefficients and transpiration of a super intensive Arbequina olive orchard using the dual $\mathrm{Kc}$ approach and the Kcb computation with the fraction of ground cover and height," Water (Switzerland), vol. 11, no. 2, 2019, doi: 10.3390/w11020383.

[20] S. O. Sulaiman, G. Al-Dulaimi and H. Al Thamiry, "Natural Rivers Longitudinal Dispersion Coefficient Simulation Using Hybrid
Soft Computing Model," 2018 11th International Conference on Developments in eSystems Engineering (DeSE), Cambridge, United Kingdom, 2018, pp. 280-283, doi: 10.1109/DeSE.2018.00056.

[21] S.O.Sulaiman, A.H.Kamel, K.N.Sayl, et al. Water resources management and sustainability over the Western desert of Iraq. Environ Earth Sci 78, $495 \quad$ (2019). https://doi.org/10.1007/s12665-019-8510-y

\section{ين المساحة المزروعة لمشروع الرمادي الاروائي باستخدام نموذج تخطيط وتقييم المياه ( WEAP )}

صادق عليوي سليمان

sadeq.sulaiman@uoanbar.edu.iq
***مصام محمد عبد الحميد

isambayati@uoanbar.edu.iq
أبو بكر أحمد نجم* ت

abubaker_ded@uoanbar.edu.iq

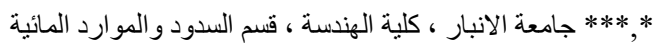

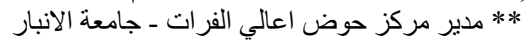

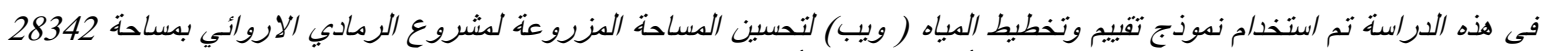

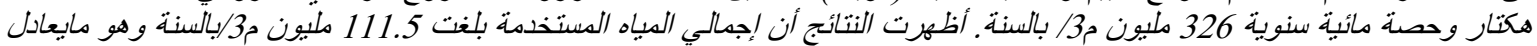

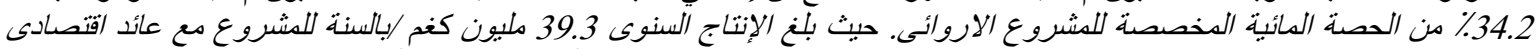

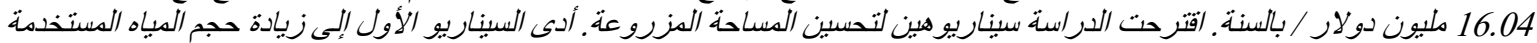

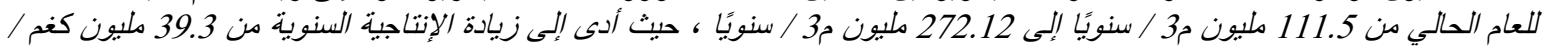

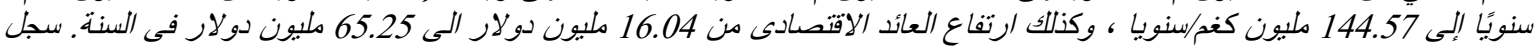

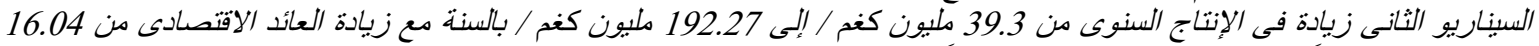

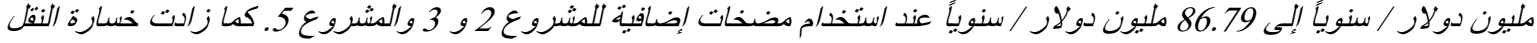

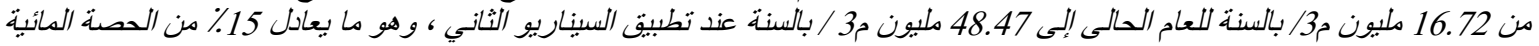
لمشروع الرمادي الاروائي.

الكلمات الد/الهه :

تحسين المساحة المزروعة ، تحسن العائدات الاقتصادية ، مشروع الرمادي الاروائي ، نموذج وبيب 